\title{
Economic Analysis of Sweet Orange Varieties in Akola District of Maharashtra, India
}

\author{
Polu Parameshwar*, P.S. Joshi and D.H. Paithankar
}

Department of Horticulture, Dr. Panjabrao Deshmukh Krishi Vidyapeet, Akola - 444 104, Maharashtra, India

*Corresponding author

\section{A B S T R A C T}

\section{Keywords}

Sweet orange,

Economic analysis,

Valencia late,

Benefit: Cost Ratio

Article Info

Accepted:

16 March 2018

Available Online:

10 April 2018

\begin{abstract}
The present study was undertaken to estimate the cost and return per hectare, the economic feasibility of investment of the Sweet orange fruit crop the study pertained to the year 2012-13. The study was based on data collected at All India Coordinated Research Project on Tropical Fruits (Citrus), Dr. Panjabrao Deshmukh Krishi Vidyapeeth, Akola (Maharashtra). The present investigation was carried out in Ambe bahar season from eight sweet orange cultivars including Pera, Pineapple, Jaffa, Washigton navel, Hamlin, Valencia late, Sathgudi and Blood red malta. It was observed that Valencia late variety showing height fruit production $\left(9.0 \mathrm{q} \mathrm{ha}^{-1}\right)$ followed by Sathgudi $\left(8.1 \mathrm{q} \mathrm{ha}^{-1}\right)$ and Pera showing lower fruit production $\left(2.8 \mathrm{q} \mathrm{ha}^{-1}\right)$. Thus, total investment per hectare of each variety was Rs. 97665/-. It was observed that the more net present worth Rs.317485. /- was obtained from Valencia late and the Benefit: Cost Ratio was 3.2 followed by Sathgudi Rs. 284235. /- with 2.91 per cent Benefit: Cost Ratio. Pera variety showing low net present worth Rs. 97790. /- with 1.0 per cent Benefit: Cost Ratio.
\end{abstract}

\section{Introduction}

Horticultural development had not been a priority until recent year in India. It is known that horticulture sector in India is constrained by low crop productivity, limited irrigation facility and under development infrastructure support like cold storages, markets, roads, transportation facilities and also there are heavy post-harvest and handling losses, resulting in low productivity per unit area. However, on the other hand, India's long growing season, diverse soil and climatic conditions comprising several agro-ecological regions provide ample opportunity to grow a variety of horticulture crops. Citrus spp. are of great importance and India is considered to be the home of Citrus spp. it is grown on the diverse condition ranging from tropical to subtropical climate, most of the tropical region of South East - Asia, especially China, India. Malaysia etc. are suitable for its cultivation. Sweet orange (Citrus sinensis Osbeck) is one of the important horticultural crops grown in India in general and Maharashtra in particular. In Maharashtra area under sweet orange was 99.0 thousand hectare with production and productivity was 245.0 thousand M.T. and 2.5 MT/ha, respectively (Anonymous, 2013). Sweet orange is a perennial crop and is 
continuous source of income generation to the farmers. It is grown widely in different districts of Maharastra, but Akola, Jalna, Aurangabad, Nanded and Parbhani are the major area in production, among them Akola is dominant in area and production. It is a commercially viable crop. Therefore, it was necessary to have an in depth study of production of sweet orange and proposed to perform an economic analysis of production of sweet orange with the following specific objectives: to study the cost and return of sweet orange and to determine economic feasibility of sweet orange.

\section{Materials and Methods}

Eight sweet orange varieties viz Pera, Pineapple, Jaffa, Washington navel Hamlin, Valencia late, Sathgudi and Blood red malta were selected for study. The studies were conducted at All India Coordinated Research Project on Tropical Fruits (Circus), Dr. Panjab rao deshmukh Krishi Vidyapeeth, Akola during 2012-13. All the trees were of same age (12 years) raised on Rough Lemon ( $C$. limon Linn. Burn) rootstock. Plan-tation was made according to randomized block de-sign (RBD). The plants were spaced at $6 \times 6 \mathrm{~m}$ and subjected to similar cultural practices throughout the growing period.

\section{Discounted measures of project worth}

Net Present Worth (NPW)

Internal Rate of Returns (IRR)

Benefit: Cost Ratio (BCR)

Net Benefit - Investment Ratio (N/K Ratio)

The formal mathematical statements of discounted measures of project worth discussed in early part are given below

Net present Worth $=\sum_{\mathrm{t}=1}^{\mathrm{t}=\mathrm{n}} \frac{\mathrm{B}_{1}-\mathrm{C}_{\mathrm{t}}}{(1+\mathrm{i})^{\mathrm{t}}}$

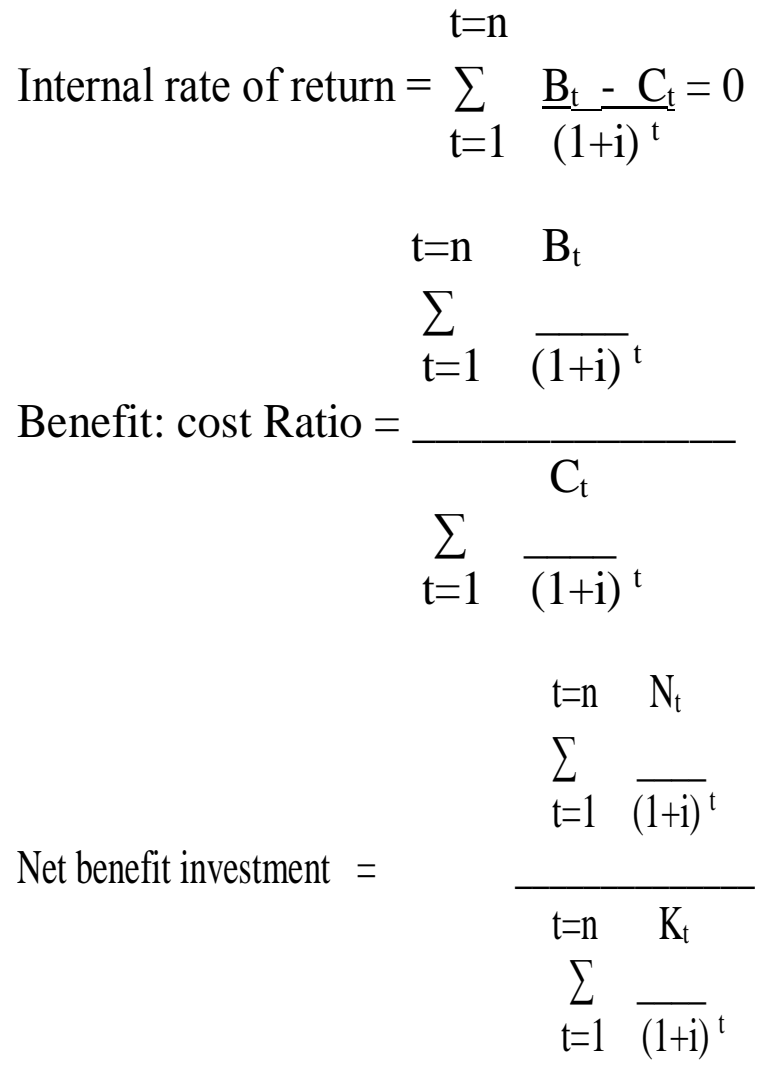

In the four mathematical formulations:

$\mathrm{Bt}=$ benefit in each year,

$\mathrm{Ct}=$ cost in each year,

$\mathrm{Nt}=$ incremental net benefit in each year after stream has turned positive

$\mathrm{Kt}=$ incremental net benefit in initial years when stream is negative,

$\mathrm{t}=1,2, \ldots, \mathrm{n}$,

$\mathrm{n}=$ number of years,

$\mathrm{i}=$ interest (discount) rate

\section{Results and Discussion}

The findings of the study as well as the relevant discussion have been presented under following. Cost of cultivation of sweet orange 
varieties per hectare per annum item wise expenditure of sweet orange varieties were calculated and are presented in the below Table 1. It was observed that total expenditure or Cost for each variety separately calculated and the cost of cultivation of different cultural methods like Harrowing with tractor
(Rs.5000/-), Labor charges (weeding, watering, fertilizer application Rs.3500/-), Fertilizers cost [N, P, K (Rs.4120/-)], FYM Cost (13850/-), weeding (Rs.1500/-) and Harvesting (Rs.6000/-) and other charges, On an average, total Cost '(C)' of each variety Rs.97665/-.

Table.1 Economics of varieties (Cost in Rs/ha)

\begin{tabular}{|c|c|c|c|c|c|c|c|c|}
\hline Particulars & Pera & Pineapple & Jaffa & $\begin{array}{c}\text { Washngton } \\
\text { novel }\end{array}$ & Hamlin & $\begin{array}{c}\text { Valencia } \\
\text { late }\end{array}$ & Sathgudi & $\begin{array}{c}\text { Bloodred } \\
\text { malta }\end{array}$ \\
\hline $\begin{array}{c}\text { Harrowing } \\
\text { (Tractor) }\end{array}$ & 5000 & 5000 & 5000 & 5000 & 5000 & 5000 & 5000 & 5000 \\
\hline Labour & 3500 & 3500 & 3500 & 3500 & 3500 & 3500 & 3500 & 3500 \\
\hline $\mathbf{N}$ & 1800 & 1800 & 1800 & 1800 & 1800 & 1800 & 1800 & 1800 \\
\hline $\mathbf{P}$ & 1686 & 1686 & 1686 & 1686 & 1686 & 1686 & 1686 & 1686 \\
\hline $\mathbf{K}$ & 634 & 634 & 634 & 634 & 634 & 634 & 634 & 634 \\
\hline FYM & 13850 & 13850 & 13850 & 13850 & 13850 & 13850 & 13850 & 13850 \\
\hline Weeding & 1500 & 1500 & 1500 & 1500 & 1500 & 1500 & 1500 & 1500 \\
\hline Harvesting & 6000 & 6000 & 6000 & 6000 & 6000 & 6000 & 6000 & 6000 \\
\hline $\begin{array}{c}\text { Cost } C \\
\text { (Total cost) }\end{array}$ & 97665 & 97665 & 97665 & 97665 & 97665 & 97665 & 97665 & 97665 \\
\hline Yield kg/ha & 2794 & 3652 & 4562 & 5592 & 5811 & 9071 & 8121 & 6467 \\
\hline $\begin{array}{c}\text { Gross return } \\
\text { Rs/ha @35 } \\
\text { Rs } / \mathbf{k g}\end{array}$ & 97790 & 127820 & 159670 & 195720 & 203385 & 317485 & 284235 & 226345 \\
\hline $\begin{array}{c}\text { Net } \\
\text { monetory } \\
\text { returns } \\
\text { Rs/ha }\end{array}$ & 125 & 30155 & 62005 & 98055 & 105720 & 219820 & 189570 & 190560 \\
\hline B: C ratio & 1.00 & 1.30 & 1.63 & 2.00 & 2.08 & 3.2 & 2.91 & 2.31 \\
\hline
\end{tabular}

Note: Cost $\mathrm{A}+\operatorname{Cost} \mathrm{B}=\operatorname{Cost} \mathrm{C}($ Total cost $)$

Profitability of each variety of sweet orange production was calculated and are presented in Table 1. With regard to per hectare profitability of sweet orange. It was observed that per hectare Valencia late showing height fruit production (fruits/plant and $9.0 \mathrm{q} \mathrm{ha}^{-1}$ ), Similar trends were observed by Mehrotra et al., (1977) reported on Valencia late and recorded maximum number of fruits per tree (101.1) on Troyer rootstock. Sathgudi second highest fruit production $\left(8.1 \mathrm{q} \mathrm{ha}^{-1}\right)$. Bajwa $e t$ al., (1972) also reported similar findings highest mean fruit yield per tree of 249.9 fruits per tree and 201.3 per tree was recorded 
in Nucellar and Sathgudi, respectively. Richardson et al., (1991) also studied performance of Nucellar and Sathgudi and reported more number of fruits (249.9) in Nucellar whereas Sathgudi produced (201.3) fruits per plant. Ahmed et al., (2006) also finding same result on evaluation of some exotic cultivars of sweet orange in Punjab conditions, better growth performance observed in Mosambi variety and also they reported more number of fruits per tree (345.75) whereas less number (87.25) fruits in Glane Navel and Nikhare (2002) reported same result in acid lime.

Pera variety showing lower fruit production $\left(2.8 \mathrm{q} \mathrm{ha}^{-1}\right)$. Gardner and Horanic (1961) reported higher yield production of sweet orange on rough lemon than sour orange rootstock. Similarly, gross return from the Valencia late was Rs. 317485/- followed by Sathgudi Rs. 284235/- and lowest gross return Rs. 97790/- from the Pera variety. In general benefit: cost ratio was 3.2 and 2.91observed Valencia late and Sathgudi respectively. Lowest benefit: cost ratio 1.0 was obtained from Pera variety of Sweet orange.

\section{References}

Ahmad, W., M.A. Prevez, M. Amjad, M. Khalid, C.M. Ayyub and M.A. Nawaz,
2006. Effect of stionic combination on the growth and yield of Kinnow mandarin (Citrus reticulate Blanco). Pakistan J. Bot., 38: 603-612.

Anonymous, 2013. Area and production of Citrus in India and Maharashtra. http//www.nhb.gov.in.

Bajwa, M.S., M.R. Gupta and J.R. Sharma, 1972. A varietal trial on sweet orange (Citrus sinensis (L) Osbeck). Punjab Hort. J., 22 (1-2): 45-47.

Gardner, F. E. and G.E. Hornic, 1961. A comparative evaluation of rootstocks for Valencia and Person Brown oranges on Lake land and fines and. Proc. Fla. sta. Hort. Soc., 74:123-7

Mehrotra, N. K., J. S. Jawanda and V. K. Vij, 1977. A Comporative evaluation of rootstocks for Blood red orange [C. Sinensis (L)] under arid-irrigated conditions of Punjab. Paper presented in the International Symposium on Citriculture, Bangalore

Nikhare, A.K., 2002. Effect of plant growth regulators on flowering, yield and quality of Hasta bahar acid lime. M.sc. (Agri.) Thesis (unpub), Dr. PDKV., Akola

Richardson, A., P. Andersen, A. Hartey and P. Sutton, 1991. Satsuma tencultivar compared. Orchardist of New Zealand, 64(2): 22-25.

\section{How to cite this article:}

Polu Parameshwar, P.S. Joshi and Paithankar, D.H. 2018. Economic Analysis of Sweet Orange Varieties in Akola District of Maharashtra, India. Int.J.Curr.Microbiol.App.Sci. 7(04): 19351938. doi: https://doi.org/10.20546/ijcmas.2018.704.221 